\title{
A personal response by a doctoral student to the work of Grace
}

\author{
How it provides an agenda for future \\ research and policy development in \\ Catholic education in the Philippines
}

\section{Joanna Marie S. Oliva}

\section{Introduction}

In the all the published books, conferences and even personal conversations with Prof. Gerald Grace, he always emphasises the important role that Catholic education is playing in the development and formation of society. He considers it as a fundamental principle that Catholic schools are in the service of the common good, not only of Catholic communities but also of the wider society. He sees that at its best, every educator in a Catholic school should have a vocation not only to educate academically but also to see their role as a mission to form the school's students into good Christians and good citizens with moral commitment and social responsibility, seeing themselves as citizens of the world and not only of one nation.

Grace remarked that one of the prime purposes of Catholic education is 'to keep alive and to renew the culture of the sacred in a profane and secular world' (Grace 2002, p. 5). It aims to educate not only to provide quality education of a secular standard but to truly enlighten the world with the beauty of sacred culture and what it is to be truly human. ${ }^{1}$ Since Catholic schools are not only educating Catholic students, Grace stresses that educating for the common good is an irreplaceable source of service for the poor and disadvantaged members of society. He also sees it as a spiritual contribution in the building up of the Kingdom of God in this life and for eternity (2000, p. 2). As a Catholic doctoral student and educator from the Philippines, I have seen and experienced the benefits of acquiring a good Catholic education. It has allowed me to advance in my knowledge and career, and it laid out a bright future for me and my future family, but Catholic education has a greater mission than that.

\section{A brief context of the Philippines}

The Philippines is a predominantly Catholic nation with an estimated 83 million baptised Catholics (Philippines Statistics Authority [PSA] 2019), which is 
why it is not surprising to see the great cultural and societal influence of the faith that is evident in various social issues. Concrete examples of this are found in a recent study, which indicated that many Filipinos have strong views that are in line with the Catholic Church teachings. Two-thirds $(67 \%)$ of the respondents said that getting a divorce is morally unacceptable - three times the share of Americans who say this (22\%). To date, the Philippines is one of the last two remaining sovereign jurisdictions that still does not legally accept divorce; the other jurisdiction is, of course, the Vatican (The Economist 2020). Filipinos strongly against abortion, saying that it is immoral (93\%); no country among the 40 surveyed is more universally opposed to abortion on moral grounds (The Pew Research Centre 2015). At the other end of the spectrum, despite the deeply rooted Catholic values as a nation, corruption is perceived to have become worse in the Philippine government, according to the Corruption Perceptions Index (CPI) survey for 2019 conducted by Transparency International; it ranked 113th of 180 countries studied on their perceived political integrity (CNN Philippines 2020). ${ }^{2}$

The Catholic Church hierarchy in the Philippines is still respected and honoured by many. However, every time there is an important and pressing issue in the society, and the Catholic hierarchy through its bishops and cardinals pronounces a view on it, many free thinkers invoke the principle of separation of Church and State. While the principle has its proper application, in a developing country like the Philippines with a predominantly and historically Catholic culture, it is much more important to foster cooperation between these two elements of the society than to simply hold them apart. Instead of speaking only about separation of Church and State, the Philippines can cultivate a healthy and responsible partnership between the Catholic Church and the Philippine government; after all, both are serving the same people. Part of that cooperation, of course, would also require pursuing and insisting on respect for the rule of law and upholding the rights and dignity of all people of other faiths, such as the sizeable population of Muslims and a growing number of other Christian denominations in the Philippines. ${ }^{3}$ It is also important that the Catholic Church stands as a prime mover for the promotion of the common good and protector of the basic human rights of those most vulnerable and disadvantaged members of society, especially the poor. ${ }^{4}$

There are around 1,500 Catholic schools and universities (Catholic Education Association of the Philippines [CEAP] 2019) spread across the country. These Catholic educational institutions provide classrooms, facilities and quality education around the country, not only in major cities but also in remote towns and the peripheries while relying mainly on their own resources and efforts. For a developing country like the Philippines, it is not surprising that quality education is almost always associated with Catholic educational institutions. Many of these Catholic education providers have been recognised as top-performing schools or universities, both nationally and even internationally. They are known to be providers of quality education, initiating advanced studies and 
research contributing to the advancement of the Philippine society. Many of the current and past leaders of the Philippines, both Catholics and peoples of other faiths, benefitted from a Catholic education. Furthermore, some Catholic educational institutions are dedicated to 'out of school youths', to the handicapped, to cultural minorities, and those in the periphery (Catholic Bishops Conference of the Philippines [CBCP] 2012). The Catholic Church, through its educational institutions, has a great opportunity to influence the character and social vision of its students. The Catholic educational institutions can consciously form and prepare their students for the future to be morally upright, instilling integrity and Christian accountability in order for them to become true Christian servant leaders and staunch promoters of the common good.

\section{Part I: Promotion of the common good in Catholic education}

For the Christian perspective of the common good, it is necessary to go back to the original identity of 'humanity' as the only creature created in the imago dei (Genesis 1:27). The goodness and dignity of each individual is defined as an image of God and has the capacity to achieve a multitude of things because man and woman ${ }^{5}$ also possesses the likeness of God. That is the primary identity of every individual.

A good Christian community therefore starts to form and thrives when it recognises its own identity as the imago dei and sees the identity of others in the same way and they all work together for a common purpose. For this reason, a Christian community should be, by definition, against all forms of prejudice, especially racism. The ministry of Jesus Christ was always inclusive and emphasised the importance of unity, regardless of the differences in race, beliefs, social status, culture and background. His mission was for the poor, outcast and marginalised, grounded in unity (see John 17:20-21). Jesus Christ prayed for unity not only of the community of his disciples but also of the whole world, and likened it to unity with the Father in the Holy Spirit as elaborated in the whole Gospel of John.

This unity in the community of disciples is evident in the way of life of the early Christian communities. Their resources and possessions are not only for their own benefit but for the common good of the whole community, as summed up in the observation in Acts 2:44-45: 'All who shared the faith owned everything in common. They sold their goods and possessions and distributed the proceeds among themselves according to what each one needed'. ${ }^{6}$

This community life and Christian teaching of sharing resources, genuine care for others and care for the poor is part of the Christian tradition. One of the earliest written references to the concept of the common good in the Christian tradition is found in the Christian literature in the Epistles of Barnabas written between 70 and $132 \mathrm{AD}$ : 'Do not live entirely isolated, having retreated into yourselves, as if you were already justified, but gather instead to seek the common good together' (Staniforth 1968, p. 162, Chapter 4, verse 10 of 
the Epistle of Barnabas). For the Catholic Church, the common good is the concern for the life of all. It calls for the exercise of prudence from each and every member of the community, most especially for those who are in authority and in a privileged position.

\section{Catholic education for the common good}

It can be argued that a distinctive position of the Catholic education is that it built on the common good. The Catholic Church is involved in education for the service of the good of society. It presupposes that every person possesses a basic dignity that comes from God and is therefore worthy of respect and thus deserves a good education. However, in the context of the Philippines this is a challenging mandate because all Catholic educational institutions are privately owned. ${ }^{7}$ It is a challenge because the poor and disadvantaged in material, social, academic or spiritual terms must be the Catholic educational institutions' primary concern. ${ }^{8}$

Grace (2016) points out that in order to serve the common good, Catholic educational work is a way of building up the kingdom of God. In order to realise this mission, it requires cooperation and partnership among every member of the school community and a willingness to collaborate with the government and its educational authorities. The challenge of achieving this in the Philippines is notable, because many of the Catholic schools in the Philippines and around the world are admitting a majority of students from wealthier families. Schools may have done this because of various reasons; it may be because of local laws, economic conditions or their need to be financially self-supporting. However, it is important that all Catholic educational institutions are consciously not turning attention exclusively or predominantly to those from the wealthier social classes. The exclusivity could initiate elitism and as The Catholic School document (1977) puts it: 'could lead to contributing towards maintaining their privileged position, and thereby continue to favour a society which is unjust' (par. 58).

\section{The role of Catholic school leaders in promoting the common good}

In bringing about the common good in Catholic education, it is the leaders of Catholic schools who have a very important role to play. They are challenged to see their role as educators not only as a profession but as a vocation. Recognising their work as a vocation allows school leaders to be witnesses and Christ-like in their dealings with children (Lydon 2011). Catholic school leaders are called to become credible witnesses of Christ in how they live their life and how they exercise their faith by serving others. They are to accompany the students in the stages of their personal growth but more importantly in their moral upbringing in preparation for their future profession as a service to society and for the common good. One helpful way of characterising this is through the metaphor of servant leadership (Lydon 2018). The goal of Catholic 
school leaders is to educate through exercising a kind of leadership that promotes a culture of service (Oliva 2019). Servant leadership ${ }^{9}$ includes taking care of the welfare of the most vulnerable, outcast and weakest of the school community; it thus ought to be highly inclusive. This is a key way of serving the common good.

Catholic school leaders have a duty to ensure that education for the common good is happening in the school community. Leadership should be seen not as a right but a responsibility. Leaders administer to the needs of the school community by being of service and providing help. In order to promote the common good, they should constantly consider the welfare of everyone and maintain the integrity of their mission in the daily functions of the whole educational system. They are called to constantly discern what is effective and what is good; what works and what makes sense; and more importantly to do things right and to do the right thing (Sergiovanni 2001).

\section{Part 2: Leadership challenges in promoting the common good}

The idea of the common good rests on a Christian optimism about human beings and how it can unite humanity towards a common purpose. It has the potential to change the way education is done and how it influences political and social life. Leaders are provoked to reflect upon the quality of the existing society and the kind of society that is ideal (Bradstock 2015, p. 16). The promotion of the common good does not deny that social conflict will happen and challenges will arise, but it assumes that since humanity is built for community, everyone will be willing to treat each other with good will and to collaborate in pursuing the common good, if understood correctly.

\section{Secular perspective versus Christian perspective of the common good}

Leading Catholic schools to achieve the common good is actually a challenging task. It is relatively easy to latch onto one aspect of the common good and fail to appreciate that achieving it is more like a journey - one which leaders keep on needing to be formed. A rigid vision of the common good can be used to silence those who disagree, especially if they are the weaker and more vulnerable group. In Catholic education, school leaders are caught in the difficult tension between an absolute notion of the 'common good' that demands a nonnegotiable practice and the common good that is seemingly impossible to define. Leaders who attempt to specify the common good can fall short of being truly common or truly good (Rowlands 2015).

Because of this tension, it is important for Catholic school leaders to interpret and teach the common good in relation to other moral commitments and principles, such as equality, stewardship, human dignity, respect for life and solidarity. The common good also has the commitment to prioritise the wellbeing of the most vulnerable members of the society, which in Catholic social 
teaching is referred to as a preferential option for the poor. ${ }^{10}$ The social teaching of the Catholic Church emphasises continually that those who are more fortunate should renounce some of their rights so as to place their goods more generously at the service of others and placing those with the least, the last and the lost at the forefront. This has been an important theme in the teachings of Pope Francis.

\section{Keeping the balance between equality and freedom}

Catholic school leaders face the challenge of keeping in balance both equality and freedom. Promotion of the common good respects the freedom and basic rights of every individual. However, it is important to be conscious that in a community composed of many and unique individuals, each one will have divergent ideas as solutions and different definitions of what is good. A risk of emphasising freedom and equality is that it could give rise to individualism in which one claims his or her own rights without wishing to be answerable for the common good. Catholic school leaders are then challenged to educate the balance of teaching equality, freedom and human rights to the students. It is legitimate for every individual to defend their own rights and the rights of their fellow citizens against the abuse of those in authority, while keeping within the limits and in consideration of the welfare of the common good drawn by the natural law and the Gospels.

\section{Rapid growth of globalisation and secularisation}

Part of the mission of Catholic school leaders is to act as counter-cultural witnesses, through being educators that strengthen the spiritual and moral upbringing of the students. Hopefully, they will challenge and change the spiritual and moral culture of the society in the future. In this way, Catholic education can serve the common good of the wider society. This is easier said than done given the dominance of globalisation, capitalism, materialism and secularisation. The idea of the common good and the reality of the materialistic and individualistic culture of the society appear to utterly incompatible. It makes the mission of Catholic school leaders in promoting the common good a difficult one.

\section{Hopes for Catholic education in the Philippines}

The mission of Catholic educational institutions in promoting the common good in the Philippines cannot be underestimated. Catholic education is contributing much in educating and in this way promoting the common good in the Philippine society. It has a long history of educating the young not just academically but also in the faith. Its graduates are the current leaders of our nation, and this should be seen as a sign of hope. 
However, the reality is more complex. According the Catholic Bishops' Conference of the Philippines (2012: Online), out of its more than 1,300 schools, there are more than 900 small, struggling mission schools spread over different parts of the Philippines, whose teachers work with missionary spirit. Many of these schools rely on their meagre resources as they strive to provide quality education to the marginalised in far-flung areas. It would be helpful if the government could provide some funding for those schools serving the most disadvantaged communities. It is undeniable that there is a healthy competition among educational institutions in terms of academic standards, which includes the Catholic educational institutions. Catholic schools are called to render service to the Church by ensuring that it is present in education and schooling for the benefit of human society. Despite the competition, it is necessary for Catholic schools to also see each other as allies and not rivals in terms of promoting the common good and maintaining the Catholic distinctiveness in the educational mission.

\section{Priorities for the future: Collaboration and sharing of best practices}

There is a huge challenge and opportunity to create more collaborative programmes and projects assisting mission schools by involving the Dioceses, Episcopal Commission on Catechesis and Catholic Education, and the Catholic Education Association of the Philippines (CEAP) in encouraging more financially stable Catholic educational institutions, wealthier Catholic school graduates and those who are in leadership positions to consciously contribute and be at the service of these mission schools who directly serve the poor and disadvantaged.

\section{Highlight the role of parents in the educational mission of Catholic education}

In the light of the great lockdown of 2020, many students found themselves forced to continue their education from home and to study remotely. Many parents struggled trying to support their children. It is important that Catholic educational institutions maintain a comprehensive effort to involve parents in the formation of their children. Highlighting their role as primary educators of their children may include pastoral and Christian formation programmes for parents and support groups in order to assist them in forming their children in the faith and reminding them that their family life would be the best witness in living out their Christian vocation and promoting the common good in society.

\section{Creating a culture of 'forming the formators'}

Continuous formation of formators in Catholic educational institutions will keep Catholic school leaders and Catholic education stakeholders grounded in their Christian commitment and morals. Having the culture of forming 
formators would allow Catholic school leaders to have regular access to pastoral training and Christian formation programmes. These programmes for all Catholic school leaders can help ensure the understanding and maintenance of the Catholic distinctiveness and educational mission of the Catholic educational institutions in promoting the common good. Formation programmes are distinct from continuing professional development programmes.

\section{Conduct more systematic scholarship and research on Catholic education}

Although Philippine Catholic educational institutions are already playing a satisfactory role in fulfilling the educational mission of the Catholic Church and there are many servant leaders, there is a need for more research. There is a need in the Philippines to emulate what Grace achieved in the UK in relation to Catholic education scholarship. Specifically, there is a strong need for more Catholic researchers and scholars to study the integrity and effectiveness of Catholic educational mission in the Philippines and globally. Empirical study would provide evidence on the contribution of Catholic education to society and will encourage a more efficient collaboration with different sectors, especially the government. There are encouraging signs that this is research is developing in the Philippines. In the journal, International Studies in Catholic Education, edited by Gerald Grace until 2021, scholars and researchers from the Philippines have contributed important articles, in particular Angelina Gutierrez (2009), Rito Baring (2010), Merceditas Ang SPC (2011), Angelina Gutiérrez (2012) and Johnny Go (2018). Their academic writings and research have raised many issues which now need further investigation. The stage is set for the field of Catholic Education Studies to grow further in the Philippines and for policy to be influenced by this research.

\section{Notes}

1 Grace has been influenced by the writing of Emile Durkheim on the sacred and profane cultures of everyday life. See Durkheim (1912).

2 For a discussion of this contradictory situation, see Gutierrez (2012).

3 The Philippine Statistics Authority reported in October 2015 that the next largest religious affiliation in the country was Islam, comprising $6 \%$ of the total population and $10.8 \%$ were other Christian denominations.

4 There are many examples of the Church in the Philippines serving the poor and marginalised, some of which include orphanages and shelters accommodating and protecting abused, abandoned, neglected and orphaned street children such as Tuloy sa Don Bosco in Paranaque City, Balay Canossa Orphanage in Cagayan De Oro, Our Lady of Victory Training Center in Davao and Rumaha Center in Quezon City.

5 Modern critics of Catholicism believe that a great opportunity was missed by the Second Vatican Council to substitute for 'men' for a more inclusive phrase such as 'all people'.

6 It is interesting to recall that when Marxists in the 19th century introduced the slogan 'From each according to his ability and for each according to his need' as indicative of communism they ignored the fact that this was the practice of early Christians. 
7 Catholic private schools in the Philippines have a commitment of providing free education and financial assistance to a commensurate percentage of the paying student population. Many also have mission schools, dedicated to serving out-of-school youths, the handicapped and those in the periphery.

8 There has been a long tradition of Catholic education in the Philippines, and this has shown a commitment to the poor. See Catholic Bishops Conference of the Philippines (2012) Pastoral Letter on 400 years of Catholic Education in the Philippines.

9 For information on servant leadership, see Punnachet (2009), in International Studies in Catholic Education.

10 For a fuller discussion of this, see Grace (2013).

\section{References}

Ang, M. SPC (2011). The Education Ministry of the Sisters of St Paul of Chartres in the Philippines: Past Achievements and Present Challenges, in International Studies in Catholic Education 3: 2, pp. 145-157.

Baring, R. (2010). A New Approach to Catechesis Involving Students in the Philippines, in International Studies in Catholic Education 2: 2, pp. 176-192.

Bradstock, A. (2015). The Unexamined Society: Public Reasoning, Social Justice and the Common Good, in Sagovsky, N. and McGrail, P. (ed.) (2015). Together for the Common Good, London: SCM Press.

Catholic Bishops Conference of the Philippines [CBCP] (2012). Pastoral letter on 400 years of Catholic Education in the Philippines (www.cbcpnews.com/cbcpnews/?p= 324), last accessed February 2021.

Catholic Education Association of the Philippines (2019) About CEAP (www.ceap.org. $\mathrm{ph} /$ who-we-are/about-ceap).

CNN Philippines (2020). Corruption in the Philippines worsens in 2019 global index (https:// cnnphilippines.com/news/2020/1/23/Philippines-corruption-worsens.html?fbclid=IwAR3 oEreKQji7onru3FviBhIE3MFkNcsgBkTZHHeeelOnXtGTefQ9pFz0mAI).

Congregation for Catholic Education (1977). The Catholic School, Vatican City: Libreria Editrice Vaticana.

Durkheim, E. (1912). The Elementary Forms of Religious Life. See new edition by Carol Cosman, Oxford World Classics, 2008.

Go, J. C. (2012). Teaching as Goal-less and Reflective Design: A Conversation with Herbert A. Simon and Donald Schön, in Teachers and Teaching 18: 5, pp. 513-524.

Grace, G. (2000). Catholic Schools and the Common Good: What This Means in Educational Practice, CIE Conference, Johannesburg, 21 September 2000, London: University of London, CRDCE.

Grace, G. (2002). Catholic Schools: Mission, Markets and Morality, London: Routledge.

Grace, G. (2013). Catholic Social Teaching Should Permeate the Catholic Secondary School Curriculum: An Agenda for Reform, in International Studies in Catholic Education 5: 1, pp. 99-109.

Grace, G. (2016). Faith, Mission and Challenge in Catholic Education. New York/ London: Routledge.

Gutiérrez, A. (2012). The Preferential Option for the Poor in Catholic Education in the Philippines: A Report on Progress and Problems, in International Studies in Catholic Education 1: 2, pp. 135-151. 
Gutiérrez, A. (2012). Does a Catholic Education have Lasting Effects on Adult Life? Reflections of Alumn from Catholic Colleges and Universities in the Philippines, in International Studies in Catholic Education 4: 1, pp. 16-34.

Lydon, J. (2011). The Contemporary Catholic Teacher: A Reappraisal of the Concept of Teaching as a Vocation in the Catholic Christian Context, Saarbrucken: Lambert Academic Publishing.

Lydon, J. (2018). Initial and On-going Formation of Catholic School Teachers and Leaders - A Perspective from the UK, in Lydon, J. (ed.). Contemporary Perspective on Catholic Education, Leominster: Gracewing.

Oliva, J. M. (2019). Situational Leadership in Catholic Schools, in The Pastoral Review 15:3.

Philippines Statistics Authority (2019). Census of Population and Housing (https://psa. gov.ph/population-and-housing/node/120080), accessed October 2020.

Punnachet, T. (2009). Catholic Servant Leadership: Going Beyond the Secular Paradigm, in International Studies in Catholic Education 1: 2, pp. 117-134.

Rowlands, A. (2015). The Language of the Common Good, in Sagovsky, N. and McGrail, P. (ed.). Together for the Common Good: Towards a National Conversation, London: SCM Press.

Sergiovanni, T. (2001). Leadership: What's In It For Schools? Oxon: RoutledgeFalmer. Staniforth, M. (Tran.) (1968). Early Christian Writings. London: Penguin Books.

The Economist (2020). Why the Philippines is the only country where divorce is illegal -Except the Vatican, of course (www.economist.com/asia/2020/02/13/why-the-philipp ines-is-the-only-country-where-divorce-is-illegal), accessed October 2020.

The Pew Research Centre (2015). 5 facts about Catholicism in the Philippines (www. pewresearch.org/fact-tank/2015/01/09/5-facts-about-catholicism-in-the-philippines/), accessed October, 2020. 